RESENHA

\title{
Integração regional: os blocos econômicos nas relações internacionais*
}

Em setembro de 2006, ao comentar a reunião do Grupo Mercado Comum (GMC) que se realizara naquele mês em Brasília, o jornalista Sérgio Léo, do Valor Econômico, comentava: "A burocracia tem suas vantagens, e uma delas é a falta de dúvidas existenciais: enquanto se debate publicamente o risco de dissolução do Mercosul, as instâncias burocráticas do bloco continuam funcionando com certa normalidade." Provavelmente não assistimos à "dissolução" do bloco, mas, sem dúvida, estamos longe de um período em que o otimismo quase generalizado com relação ao Mercosul justificava-se sem maiores explicações e as notícias dos jornais o reproduziam abundantemente. $\mathrm{O}$ que se passou desde então?

Aos interessados em conhecer não só o processo de construção do Mercosul, mas também a história e os principais desafios atuais encontrados em vários processos de integração econômica pelo mundo, uma boa pedida é a leitura do livro de Alfredo da Mota Menezes e Pio Penna Filho. Em linguagem bastante acessível, o livro dirige-se ao leitor não-especialista, que poderá compreender esse fenômeno internacional. Quais as diferenças entre uma união aduaneira e uma zona de livre comércio? A integração deve melhorar o bem-estar social das sociedades integradas, mas como integrar economias tão díspares como as da Alemanha e de Portugal ou como as do Brasil e do Paraguai? Embora, em geral, a integração seja vista pelo cidadão comum como uma forma a ser buscada para que os países atinjam um bom padrão de inserção internacional, obstáculos das mais diversas naturezas devem ser enfrentados, e os de natureza política não são os menores deles.

O capítulo introdutório do livro de Menezes e Penna Filho trata das diferentes perspectivas conceituais quanto à integração econômica e de suas características e possíveis gradações. Para ilustrar as difíceis marchas e contra-

\footnotetext{
* Resenha de MENEZES, Alfredo da Mota; PENNA FILHO, Pio. Integração Regional: os Blocos Econômicos nas Relações Internacionais. Rio de Janeiro: Elsevier, 2006. ISBN 13: 978-85-352-2024-7 e 10: 85-352-2024-7.

** Professora do Instituto de Relações Internacionais da Universidade de Brasília - UnB (breda@unb.br).
} 
marchas de um processo de integração, os autores tratam da Alalc (Associação Latino-Americana de Livre Comércio), criada em 1960, e de sua sucessora, a Aladi (Associação Latino Americana de Integração), criada em 1980). Sobre essas experiências, comentam: "Não prosperaram, tiveram problemas e morreram anos depois. No entanto", continuam, "não deixaram de ser úteis como aprendizado para uma região que, desde o período colonial, não pratica um comércio regional ativo".

Em outro capítulo, dedicado à integração no continente americano, o leitor poderá constatar os avanços posteriores à criação da Aladi. O capítulo contempla a Comunidade Andina (CAN), o Mercado Comum Centro Americano (MCCA), a Comunidade Caribenha (Caricom), a Área de Livre Comércio das Américas (Nafta) e o Mercosul. Poderá também compreender os comentários lacônicos do jornalista Sérgio Léo, transcritos acima. Assim, compreenderá por que estamos um tanto distantes do otimismo da década de 1990, quando o Tratado de Assunção foi assinado pelos presidentes da Argentina, do Brasil, do Paraguai e do Uruguai, dando origem ao Mercado Comum do Sul (1991). De fato, ver-se-á que a dimensão propriamente comercial do Mercosul, ao longo da década, justificava plenamente o entusiasmo com relação ao seu futuro. As trocas comerciais no interior da área integrada cresceram significativamente no período, bem como o comércio com outros países. Desde então, o bloco tem passado por várias crises, algumas das quais relacionam-se com as negociações para a formação da Alca, impulsionadas pelo governo norte-americano.

A União Européia, pela relevância que adquiriu o processo de integração europeu, que tem mais de cinqüenta anos, mereceu um capítulo do livro. Com efeito, essa é considerada uma realização paradigmática, quando se trata de integração regional. A história de um continente fortemente marcado pelo nacionalismo e pelas guerras, e que chegou ao mais avançado dos processos de integração no mundo "tem servido de exemplo e inspiração para vários outros esquemas de integração". Hoje, a União conta com 22 países e conseguiu mostrar um fôlego sem precedentes, ainda que se saiba das várias divergências existentes entre os países que a compóem. Os problemas em torno da Política Agrícola Comum (PAC) é apenas uma delas, com a qual, inclusive, os países do Mercosul passaram a ter uma triste familiaridade, em conseqüência do protecionismo do qual são objeto.

Dois capítulos ainda ocupam-se da Ásia e da África, continentes pouco contemplados nos estudos brasileiros sobre integração regional. No capítulo sobre a Ásia, região cuja economia apresenta um enorme dinamismo, apresentando taxas de crescimento que estão entre as maiores do mundo, os dois blocos principais são apresentados: a Associação das Nações do Sudeste Asiático (Asean) e a Conferência Econômica para a Região Ásia-Pacífico (Apec). A Asean, fundada em 1967, e a Apec, criada bem mais recentemente, em 
1989, têm dinâmicas internas que se diferenciam da União Européia e dos processos do continente americano e que, em boa medida, tem a ver com a posição estratégica do continente e seu relacionamento com os Estados Unidos. A integração na África também tem particularidades, que estão distantes do caráter dinâmico da economia asiática. De fato, esse continente que aparenta exaustão econômica, também apresenta processos de integração mais difíceis, dentre os quais são estudados pelos autores a Comunidade Econômica dos Estados da África Ocidental (Ecowas) e a Comunidade para o Desenvolvimento da África (Sadc), criadas em 1975 e em 1992, respectivamente.

Enfim, o livro de Menezes e Penna Filho tem muitos méritos, dentre os quais, vale insistir, estão a sua linguagem acessível, sem tecnicidades, e sua larga abrangência, ao estudar os processos de integração regional mais importantes no mundo. Ao leitor, boa leitura! 